International Journal of Civil, Structural, Environmental and Infrastructure Engineering Research and Development (IJCSEIERD) ISSN (P): 2249-6866; ISSN (E): 2249-7978

Vol. 11, Issue 1, Jun 2021, 103-114

(c) TJPRC Pvt. Ltd.

\title{
CORONA VIRUS IMPACT AND PURIFICATION OF SEWAGE WATER TREATMENT THROUGH THE SOLAR STILL
}

\author{
SURESH NATRAYAN ${ }^{1}$ JAYAPRAKASH RAJAN $*^{2}$ VISHALASHI BABUPRASATH ${ }^{3}$ \\ \& SENTHIL VENKATESAN ${ }^{4}$ \\ ${ }^{1}$ Research Scholar, Research and Development Centre, Bharathiar University, Coimbatore, Tamilnadu, India \\ ${ }^{1}$ Department of Physics, Hindusthan College of Arts and Science, Coimbatore, Tamil Nadu, India \\ *2 Department of Physics, Sri Ramakrishna mission Vidyalaya College of Arts and Science. Coimbatore, Tamil Nadu, India \\ ${ }^{3}$ Department of Physics, Hindusthan College of Arts and Science, Coimbatore, Tamil Nadu, India \\ ${ }^{4}$ Department of Physics, Hindusthan College of Arts and Science, Coimbatore, Tamil Nadu, India
}

\begin{abstract}
The Sewage remedy method is to cast off the various substances of the polluting load: solids, natural carbon, nutrients, inorganic salts, metals, pathogens and so forth. The ordinary primary and secondary remedy methods of those wastewaters were added in a developing amount of locations, in case you need to remove the without problems settled substances and to oxidize the natural material found in wastewater. This paper evaluations using waste water remedy technology to put off contaminants from wastewater consisting of halogenated hydrocarbon compounds, heavy metals, dyes, pesticides, and herbicides, which represent the primary pollutants in wastewater. The purification method may be very distinguished to get excessive purified rate water. Here it's miles used that sun nevertheless purification approach to purify the sewage water. And moreover have a look at approach within the direction of the Corona virus in sewage water remedy and significance.

KEYWORDS: Cornona, Wastewater, Compounds, Public, Health, Environment, Minerals
\end{abstract}

Received: Apr 08, 2021; Accepted: Apr 28, 2021; Published: Apr 30, 2021; Paper Id.: IJCSEIERDJUN202111

\section{INTRODUCTION}

However, conventional waste treatment technologies are expensive. Consequently, several research efforts are running to develop low-cost treatment technologies appropriate in developing countries M. A. El-Khateeb et.al 2019 [1]. Furthermore, during the last few decades, stringent regulation of waste discharge into the environment is receiving wider attentions. In order to achieve cost-effective technologies, natural materials such as rocks and sands are widely applied in wastewater treatment for removing pollutants S. Ahsan et.al 2001[2]. Several studies centered on the use of low-cost, extremely efficient pollutant sorbents and also examined the sorption activities of several recycled materials and chemicals C. O. Ijagbemi et. Al 2009[3]. Ali et al. [4] conducted the adsorption of harmful pollutants from wastewater applying natural zeolite. The results suggest that clinoptilolite removal for ammonium varied from 70 to 92 percent, whilst at different circumstances, it varied from 70 to 99 percent for heavy metals. Bhattacharya et al. [5] examined the adsorption performance of zinc from an aquatic environment with different adsorbents; 


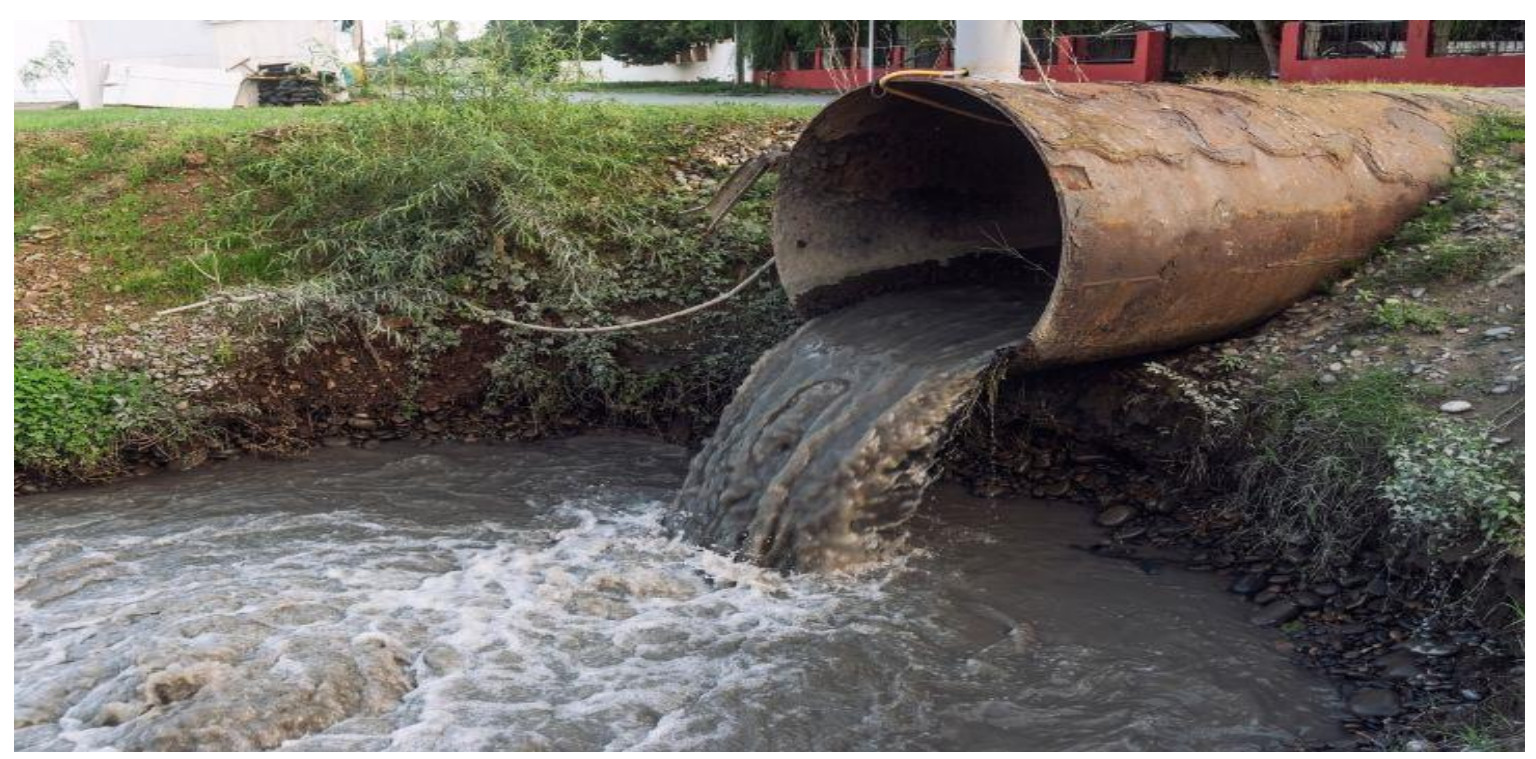

Conventional water and wastewater treatment processes have been long established in removing many chemical and microbial contaminants of concern to public health and the environment. However, the effectiveness of these processes has become limited over the last two decades because of three new challenges (Langlais et al. 1991; Mallevialle et al. 1996) [6]. Wiesner et al. (1994)[7] concluded that the costs of new pressure-driven membrane filtration plants are expected to be comparable with or even less than those using conventional treatment processes for capacities up to $20000 \mathrm{~m}^{3} / \mathrm{day}$. Reclaimed wastewater is a proven and reliable source of water in many regions of the world. The technologies available for treating domestic wastewater, to levels sufficient for unrestricted uses of reclaimed water are expensive to both construct and to operate. The use of macrophyte (wetland) systems for wastewater treatment as a low-cost technology has increased during the past decades Perkins and Hunter, 2000) [8].

These clinical observations imply that municipal wastewater of affected communities might contain the virus. Wastewater-based epidemiology (WBE) is a promising approach to understand the prevalence of viruses in a given wastewater treatment plant (WWTP) catchment population, because wastewater contains viruses excreted from symptomatic and asymptomatic individuals in a catchment (Sinclair et al., 2008; Xagoraraki and O'Brien, 2020) [9]. Recently published RT-qPCR assays were used for the detection ofSARS-CoV-2 RNA in wastewater samples (Corman et al., 2020; Shiratoet al., 2020)[10]. The reported symptoms of COVID-19 pa-tients include cough, fever, difficulty in breathing and diarrhea, andSARS-CoV-2 ribonucleic acid (RNA) has been detected in feces of not only symptomatic but also asymptomatic patients (Gao et al., 2020;Holshue et al., 2020;Jiehao et al., 2020;Tang et al., 2020;Wölfel et al., 2020; Zhang et al., 2020a; Zhang et al., 2020b)[11]. Feces are composed of water, protein, undigested fats, polysaccharides, bacterial biomass, ash, and undigested food residues. The major elements in feces as a percentage of wet weight are oxygen $74 \%$, hydrogen $10 \%$, carbon $5 \%$, and nitrogen $0.7 \%$, including the hydrogen and oxygen present in the water fraction of the feces (Snyder et al., 1975)[12]. Knowledge of the waste that enters treatment systems is a basic prerequisite for the design and development of future technology. There is information on conventional sanitary sewage (Henze et al., 2001; Tchobanoglous et al., 2003)[13]

These days many water assets are polluted via anthropogenic assets together with household and agricultural waste and commercial methods. Public subject over the environmental impact of wastewater pollutants has improved. Several conventional wastewater remedy strategies, i.e. chemical coagulation, adsorption, activated sludge, have been 
carried out to take away the pollutants, however there are still some barriers, mainly that of high operation charges. The use of cardio waste water treatment as a reductive medium is receiving multiplied hobby because of its low operation and upkeep prices. Further, it is easy-to-obtain, with desirable effectiveness and potential for degrading contaminants. Sewage/Wastewater treatment operations are accomplished with the aid of various techniques so that it will reduce its water and organic content material, and the remaining goal of wastewater control is the protection of the environment in a way commensurate with public fitness and socio-financial concerns. Re-use is an important and herbal technique of managing drainage water. So one can increase the most advantage from a water supply and to assist put off drainage waters, strategies for water re-use have evolved. Water re-use should be balanced in opposition to both short and long-term wishes, with attention for both nearby and off-web page effects. In areas in which irrigation water elements are restricted, drainage water can be used to supplement them. However, the satisfactory of the drainage water determines which crops may be irrigated. Fantastically saline drainage water cannot be used to irrigate salt-sensitive crops. Saline drainage water is being successively re-used for the irrigation of salt-tolerant vegetation and bushes. In which an irrigation challenge is placed near a natural wetland, the drainage water may be re-used within the wetland. However, precautions will have to be taken to make certain that the first-class of the drainage water does now not harm fish, waterfowl or different wildlife inside the wetland and that the amount of water passing thru the wetland is enough to prevent toxic.

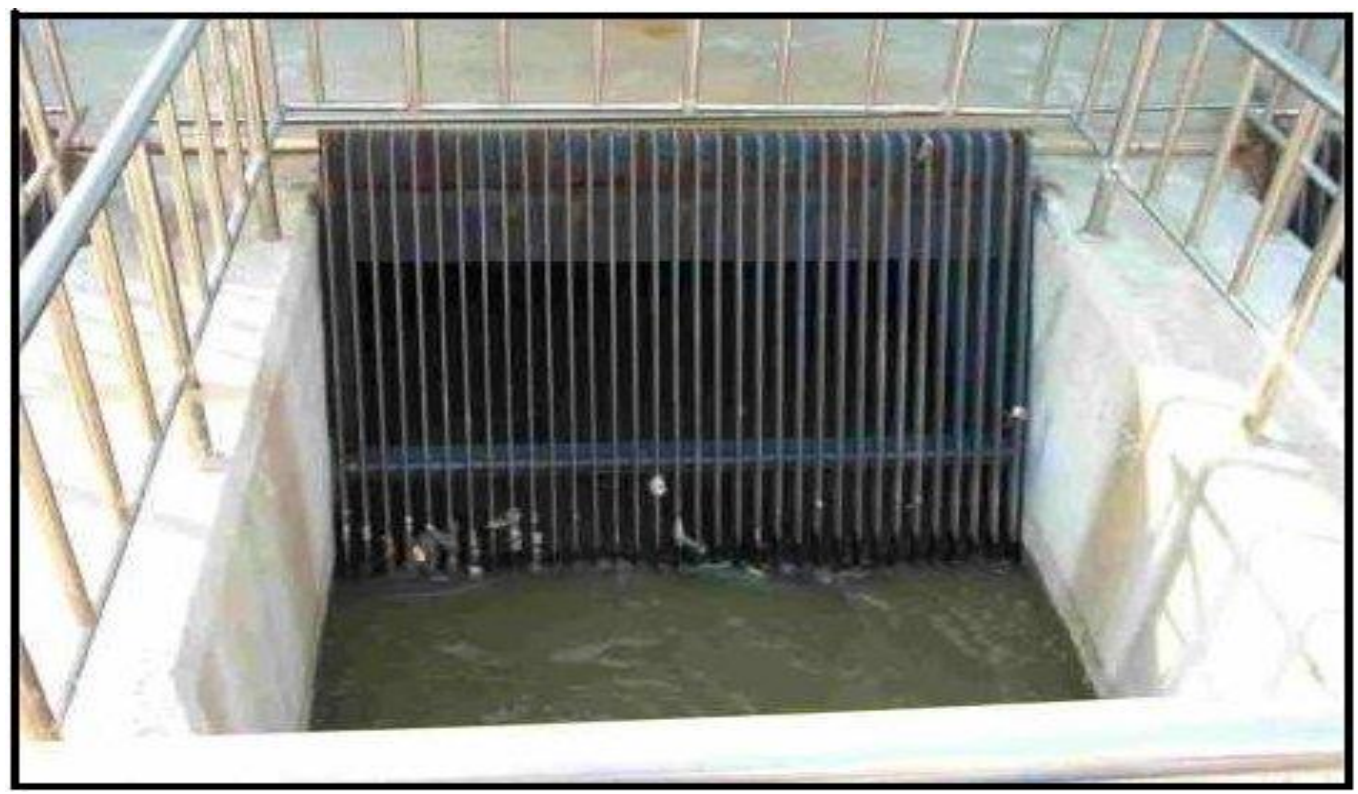

\section{Drainage Water in Plantation}

The most important degradation thing of re-used waters is the high awareness of ions. Waters with low ionic concentrations offer flora with an adequate deliver of many of the essential vitamins needed for boom. But, as salinity will increase, specific ions might also become poisonous or intrude with the uptake of different vitamins. In soils, the buildup of ions increases the osmotic potential in opposition to which flowers extract water. It can also degrade soil structure. Drainage and leaching of salts from the basis quarter are key factors in the control of salinity in agriculture. Every other control aspect is manipulate of the range of salt tolerance expressed in crop species. Water re-use for agricultural crops has distinct economic incentives and some of plants are known to be incredibly tolerant to salinity. But, as salinity increases 
within the irrigation water, there is a more need to monitor and control irrigation and drainage practices and to don't forget the sustainability of the system.

Best water requires selection of crops with appropriate salt tolerances, upgrades in water management, and renovation of soil shape and permeability. While touchy crop growth stages which include germination and early explosion are excluded, the temporal weighted suggest root area salinity has been determined to be a legitimate degree for evaluating crop response to salt. The mathematics imply root sector salinity in the rooting intensity incorporated over the time of publicity is an effective approximation for estimating crop response.

\section{Re-Use of Surface Drainage Water}

where in drainage water is derived from only floor drainage or tail water sources, the primary question is whether or no longer the water contains implemented and continual pesticides. In areas wherein strong environmental safeguards exist and pesticide container label regulations are followed, there's little danger associated with the re-use of surface runoff or tail water drainage water. Most of the floor derived drainage water is used to flood wetlands within the early autumn. Within the rice developing regions, the fields are drained within the late summer time or early autumn. This drainage sample coincides with the autumn migration of the waterfowl to their wintering grounds. Preferably, the winter waterfowl habitat is flooded to a depth of $20-50 \mathrm{~cm}$. Relying on soil kind, leakage and evaporation prices, the drainage water required for preliminary flooding will variety from 500 to $1500 \mathrm{~m} / \mathrm{ha}$. Wherein local resources of surface derived drainage water are available, water is used to maintain ponds from October to March. In heat climates, the annual evaporation or consumptive use is about $2500 \mathrm{~m}^{3} / \mathrm{ha}$, which reasons a similarly salt attention explosion inside the wetland outflow. Standard local marsh vegetation grown with surface agricultural drainage waters encompass: Water is applied in the autumn of the 12 months and held till spring soil temperatures begin to warm. This happens in March or April within the crucial Valley of California. while the soil starts off evolved to warm, the ponds are tired to mudflat conditions. This stimulates seed germination. In a few regions they require no extra water till the fall flood-up period. But, where summers are warm and dry, they may require one or greater irrigations in July or early August to offer for top-quality seed production for migrating natural world food.

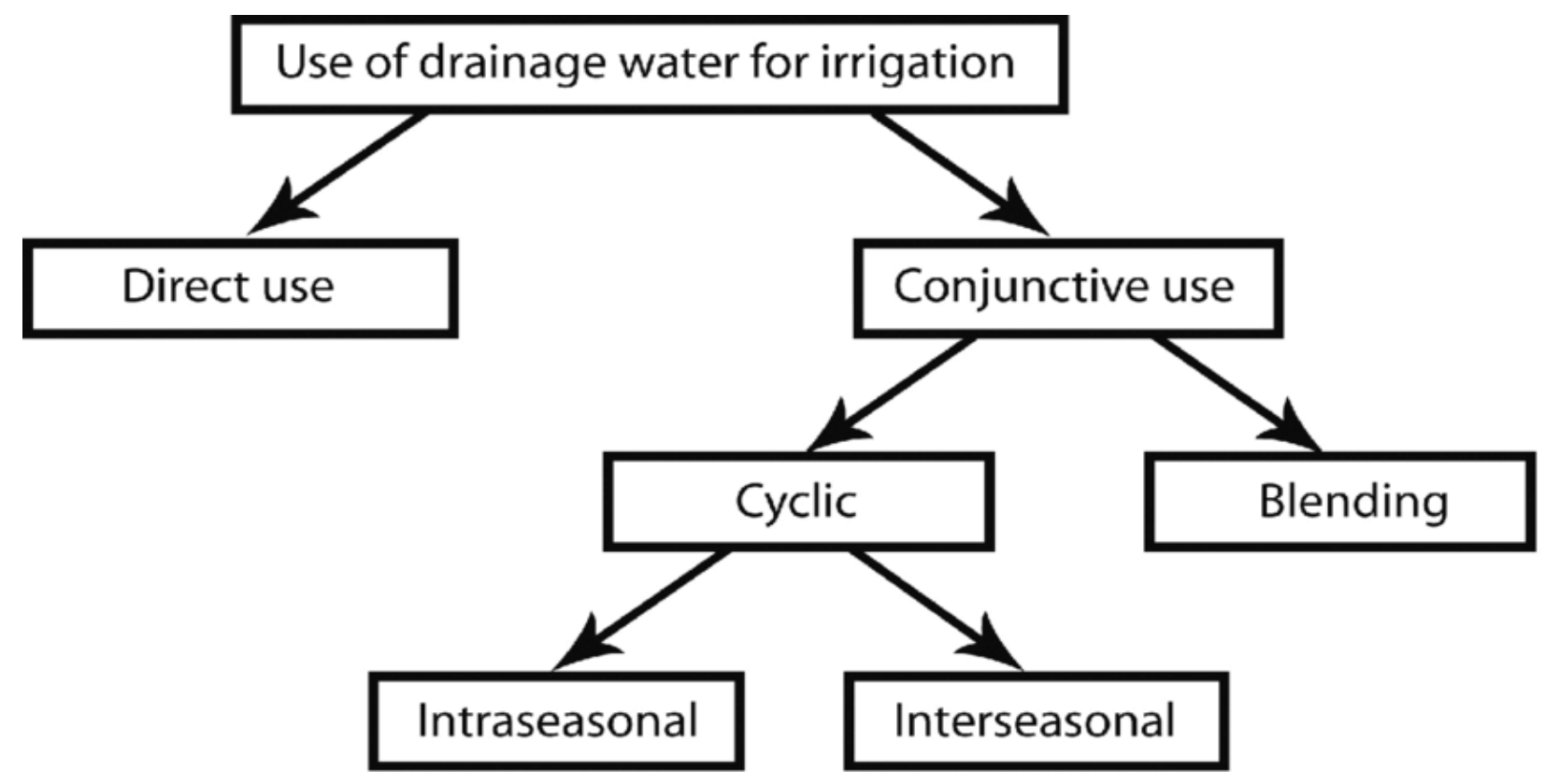




\section{Re-Use of Subsurface Drainage Water}

The re-use of subsurface saline agricultural drainage water for wetland control poses good sized challenges and can generate troubles that may result in wildlife losses and habitat reductions. despite the fact that subsurface saline drainage water is typically loose from contamination with the aid of applied pesticides or herbicides, it could incorporate soil or naturally derived toxicants or trace factors including salts, nitrates, $\mathrm{As}, \mathrm{B}, \mathrm{Cd}, \mathrm{Cr}, \mathrm{Pb}, \mathrm{Hg}, \mathrm{Mo}, \mathrm{Ni}, \mathrm{Se}, \mathrm{Ag}, \mathrm{U}$ and $\mathrm{V}$. every of these elements is potentially toxic independently, in aggregate with different constituents, or thru the technique of biomagnification in wildlife through the meals chain. Careful analysis of subsurface agricultural drainage water in the course of several durations of a every year cycle is required earlier than any plans for re-use as a water deliver for wetlands may be taken into consideration. the supply of an good enough extent of float-via water is important to reduce attention of toxic factors due to evaporation. At gift, there are not any complete requirements which set up safe tiers of hint elements in water used for wetland habitat control. However, due to the excessive potential for meals-chain magnification, most wetland managers deliberately refuse to apply subsurface agricultural drainage waters which comprise levels of hint factors above historical past stages. The ability for, and the expenses of, smooth up or remediation of a contaminated wetland dictate a conservative technique. In which trace detail contamination is not a problem, saline drainage water can be used to help a productive wetland habitat. The essential consideration is the management of soil and water salinity. The maintaining of a salt stability among the applied water and the soil/water interface is key to the production of brackish water native marsh vegetation. In widespread, water with a TDS level of two $500 \mathrm{mg} /$ litre or less is most advantageous for wetland management. once in a while, water with a TDS stage as high as five $000 \mathrm{mg} /$ litre can be used for short periods. Popular management practices contain an autumn flooding to a intensity of approximately 20-50 cm, with these depths being maintained until January or February. In past due wintry weather, the ponds are tired to discharge drainage water and accrued salts. The ponds are then refilled with new water as deeply as plausible. After about 14 days, the water is tired once more. The drainage cycle is repeated two to a few times before the cycle is completed. This manner removes salt concentrated in the surface water thru evaporation and allows for a rebalancing of the water/soil salt equilibrium. The ponds are drawn down to a mudflat country in March or April to facilitate germination of suitable salt-tolerant marsh flora. Ordinary plants grown under this regimen include: alkali bulrush (Scirpus robustus), brass buttons \{Cotula corinopifola), salt grass (Distichilis spicata) and tules (Scirpus acutus). depending at the neighborhood soil and climate, one or greater shallow irrigations can be vital to carry germinated flora to full adulthood. In all cases, so that it will save you extra salt accumulation, water movement is maintained whilst the ponds are full of saline drainage water, and some consistent rate of discharge or outflow from the ponds is vital. By preserving water circulation and a few steady fee of water flow, outbreaks of waterfowl disorder can also be avoided. Any wetland habitat supported mainly with saline agricultural drainage water need to be cautiously managed and monitored to have effective wetlands. Further, there should be an environmentally safe manner (ocean, large river, salt lake) of disposing of the water as it's miles drained from any wetland place. 
The ordinary wastage water produced through the character human are extra than 20 litres. the collection of sewage in our area is extra than 50000 litres. So, due to the demand of water in arid areas, need to discover the new purification technique to solve the shortage of water. The reusable method is assist us to transform the sewage water into pure water. So The everyday drainage water is authorized to three tank technique, then it's far taken into single slope sun still for everyday purification.

\section{The Interactions between Drainage, Water Management and Health}

Proper surface and subsurface drainage to put off extra water in a safe and well timed manner performs an essential position in controlling water related illnesses. Careful control and suitable reuse of drainage water can help defend the environment and optimize the use of water sources.

The health problems associated with drainage water control can be grouped in 3 classes:

- Water related vector-borne illnesses;

- Faecal/orally transmitted sicknesses; and

- Continual fitness problems associated with publicity to residues of agrochemicals.

In tropical and subtropical regions there's a close hyperlink between the presence of extra water (due to lack of ok drainage) and the transmission of water associated vector-borne sicknesses. Malaria, schistosomias is (bilharziasis) and lymphatic filariasis are vital water related vector-borne illnesses. Despite control programmes, health services and to be had treatments, these illnesses these days represent a growing health hassle.

Water associated vector-borne illnesses are because of bacteria, viruses and parasites (protozoa and helminths) transmitted through water related sickness transmitting dealers, additionally referred to as vectors or intermediate hosts. A vector is an animal, often an insect, that transmits an infection from one man or woman to another character or from inflamed animals to people (Cairncross and Feachem, 1983). Maximum infections can best be transmitted by means of a specific, sickness-unique vector, e.g., malaria by means of Anopheles mosquitoes. An intermediate host has a comparable function to a vector. but, such an organism does no longer actively transmit a pathogen, like freshwater snails in the case of schistosomiasis. Vectors and intermediate hosts represent crucial factors in diverse sickness transmission cycles of parasitic water associated diseases. In popular, they live in or near aquatic environments.

Direct pathogen switch and the transmission by means of vectors and intermediate hosts require unique environmental and socio-monetary conditions. The conditions are described with the aid of:

- Great and amount of water;

- $\quad$ Type and frequency of human-water contacts;

- Variety and distribution of vector or intermediate host breeding sites; and

- Publicity of people to vector and intermediate host populations.

Therefore, the above-noted illnesses also can be related both directly or not directly with the design and management of treatment and disposal plants for the re-use, treatment or disposal of drainage water. the key criteria for any such fitness threat are:

- Introduction of temporary or everlasting open water surfaces bodies, e.g., built wetland, stabilization ponds, or evaporation ponds; 
- Suitability of such water for vector breeding;

- Accessibility for the local populace;

- Place with regards to human settlements and transport hyperlinks (e.g., roads); and

- Pollution via natural or inorganic materials.

Misuse and lack of protection are the two important reasons why drainage systems (street drainage ditches, culverts, dam website drainage or drainage canals in irrigation schemes, and additionally drainage water treatment and disposal facilities) are often associated with environmental fitness problems. Farmers, associations or national organizations typically conduct ordinary upkeep on irrigation canals. Water high-quality and drift velocity are particularly excessive. However, in drainage centers the opposite situations are frequent. Silting, uncontrolled aquatic weed growth, slow water flow or stagnant pools associated with the ensuing wetlands provide ideal breeding situations for mosquitoes and aquatic snails. Farmers appear to pay attention on irrigation water control instead of on drainage management.

Furthermore, there is often a lack of adequate domestic water components and sanitation centers. hence, drainage canals or drainage water remedy and disposal facilities are regularly misused for laundry, drinking and out of control disposal of human excreta or other waste by using the poorest and, for this reason, maximum susceptible social groups. On this way, drainage water contributes to ailment transmission.

\section{Impact of Corona virus}

The research network has to locate evidence of survival of infective COVID-19 virus in feces and in wastewater systems. Efforts are ongoing to assess the relative risk of publicity to wastewater. Modern-day efforts estimate numbers of infections within the community and aid public health surveillance by detecting the virus in wastewater using molecular techniques that discover presence and quantities of genetic fabric (RNA). This approach does not investigate virus viability or infectivity. Destiny research on COVID-19 virus is encouraged to research concentrations of infective virus in feces (if any), shedding patterns in sufferers and factors influencing staying power of infective virus in plumbing and collection structures

Research is ongoing, but specialists presently agree with that exposure to wastewater isn't a significant transmission path for COVID-19 virus.

WEF continues to work on improving safety of wastewater workers from pathogen exposure - in particular through aerosols - through forming a Blue Ribbon Panel to address the issue of required non-public protecting gadget, as well as protective work and hygiene practices.

Implications for water specialists: whilst much continues to be unknown approximately COVID-19 virus losing and transmission, CDC and WHO nation that cutting-edge evidence does no longer guide that COVID-19 virus is transmitted via wastewater.

Water experts ought to be able to speak that the detection of COVID-19 virus RNA in wastewater does not translate to public fitness threat and does now not result in the want for alternate in operations or methods by way of utilities. The initial information from dealt with effluent suggests that wastewater remedy processes which are in location already are enough for COVID-19 virus manage. This information corresponds with CDC, OSHA, WHO, and WEF hints. The statistics comprised of surveillance of RNA should imply the size of the outbreak and useful resource in emergency 
reaction making plans in groups and at utilities (i.e., prediction of absenteeism and critical staff control), however those data want to be interpreted with caution.

\section{RESULT AND DISCUSSION}

\section{Triple layer: Time VS Temperature}

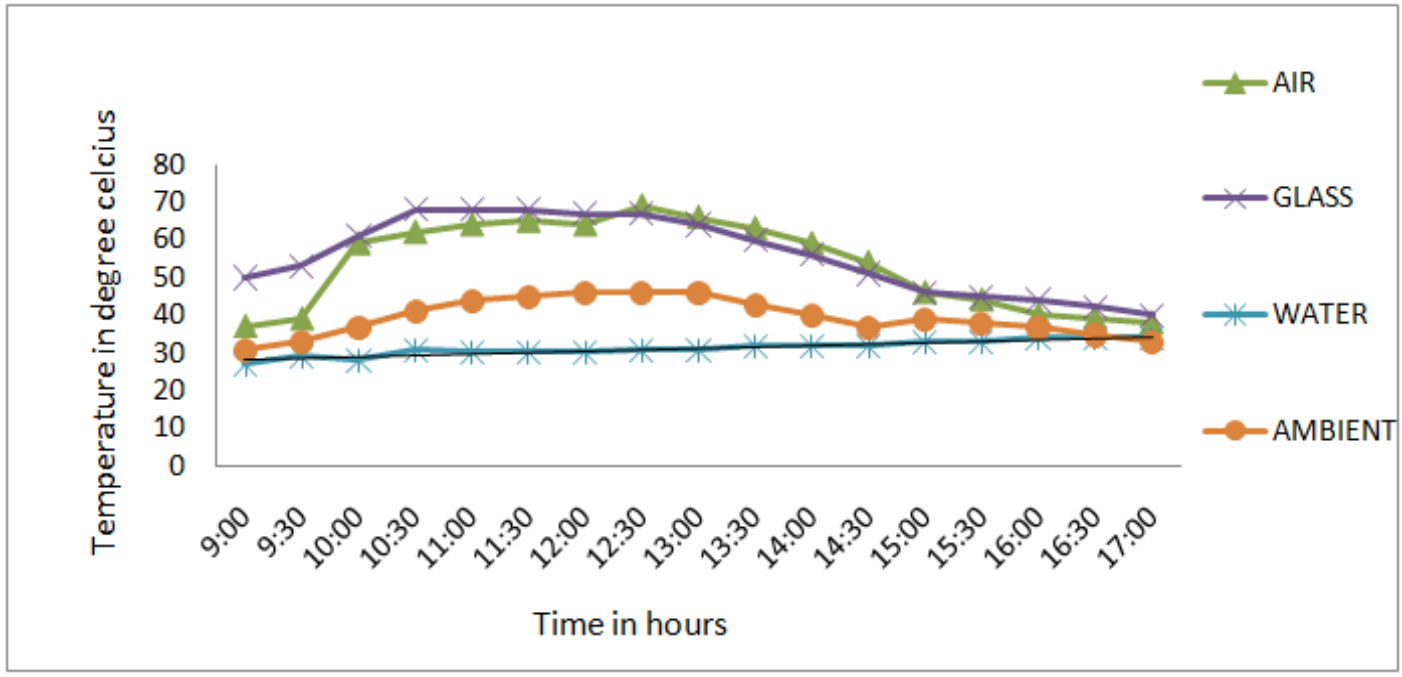

Figure 2a: Show the Triple layer of Variation of Insolation with Respect to Time.

It increases lineary with time and reaches the maximum value from 12 to $2 \mathrm{pm}$ and then decreases. Radiation received during this study is in the range of $560 \mathrm{~W} / \mathrm{M} 2$ to $869 \mathrm{~W} / \mathrm{M} 2$ for with floating and also it represents the variation of efficiency of the still with respect to time. The variation of the efficiency is obtained in the range of $3 \%$ to $7 \%$ during the study of triple layer.

\section{Triple layer: No. of days VS Radiation and Efficiency}

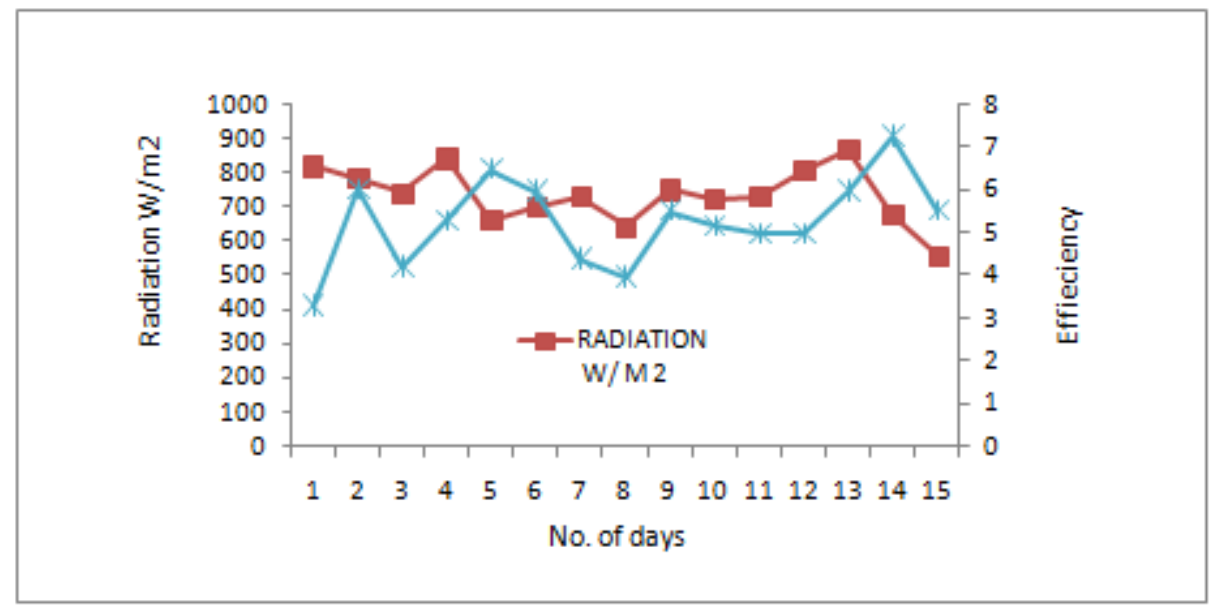

Figure $2 \mathrm{~b}$ shows Triple layer that variation of temperature for water, air, top cover ambient, inner cover and outer cover with respect to time for with floating. The maximum temperature rise in water is $34^{\circ} \mathrm{C}$. Similarly the maximum air 
temperature of $69^{\circ} \mathrm{C}$ is observed. During this study, the corresponding variation in ambient temperature is in the range of $31{ }^{\circ} \mathrm{C}$ to $46^{\circ} \mathrm{C}$ and the variation of top cover temperature is in the range of $40{ }^{\circ} \mathrm{C}$ to $68{ }^{\circ} \mathrm{C}$.

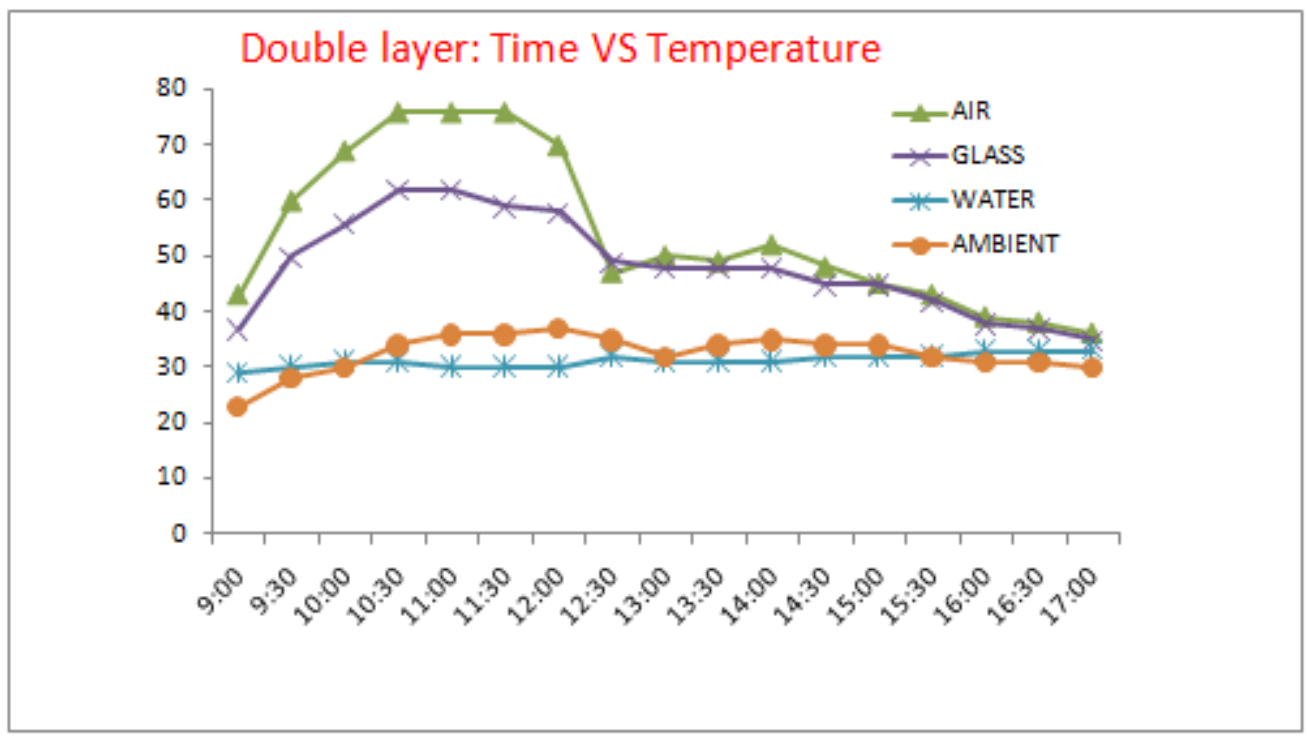

Figure $3 \mathrm{~b}$ shows the Double layer variation of temperature under insolation.

The temperature rise in the water is $33^{\circ} \mathrm{C}$. Similarly the maximum air temperature of $76{ }^{0} \mathrm{C}$ is observed. During this study, the corresponding variation in ambient temperature is in the range of $27{ }^{0} \mathrm{C}$ to $37{ }^{0} \mathrm{C}$ and variation of top cover temperature is in the range of $34 \mathrm{oC}$ to $47 \mathrm{oC}$. The impact of the ambient temperature leads to more condensation

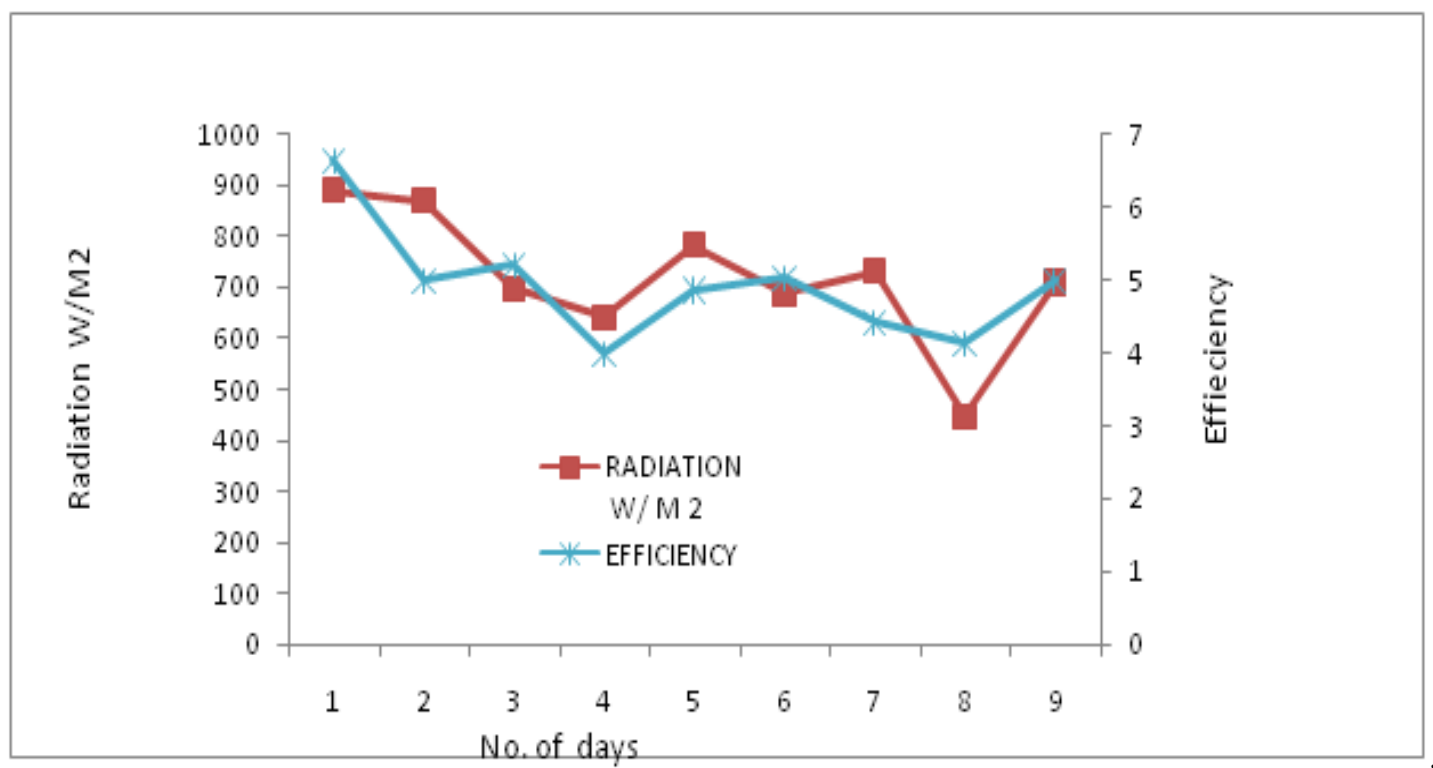

Figure $3 \mathrm{~b}$ shows variation of the daily mean solar radiation recorded during this study. In this study mean daily radiation is obtained in the range of $447 \mathrm{~W} / \mathrm{M} 2$ to $888 \mathrm{~W} / \mathrm{M} 2$ is recorded and the variation of the efficiency is obtained in the range of $4 \%$ to $7 \%$ during the study of double layer. 


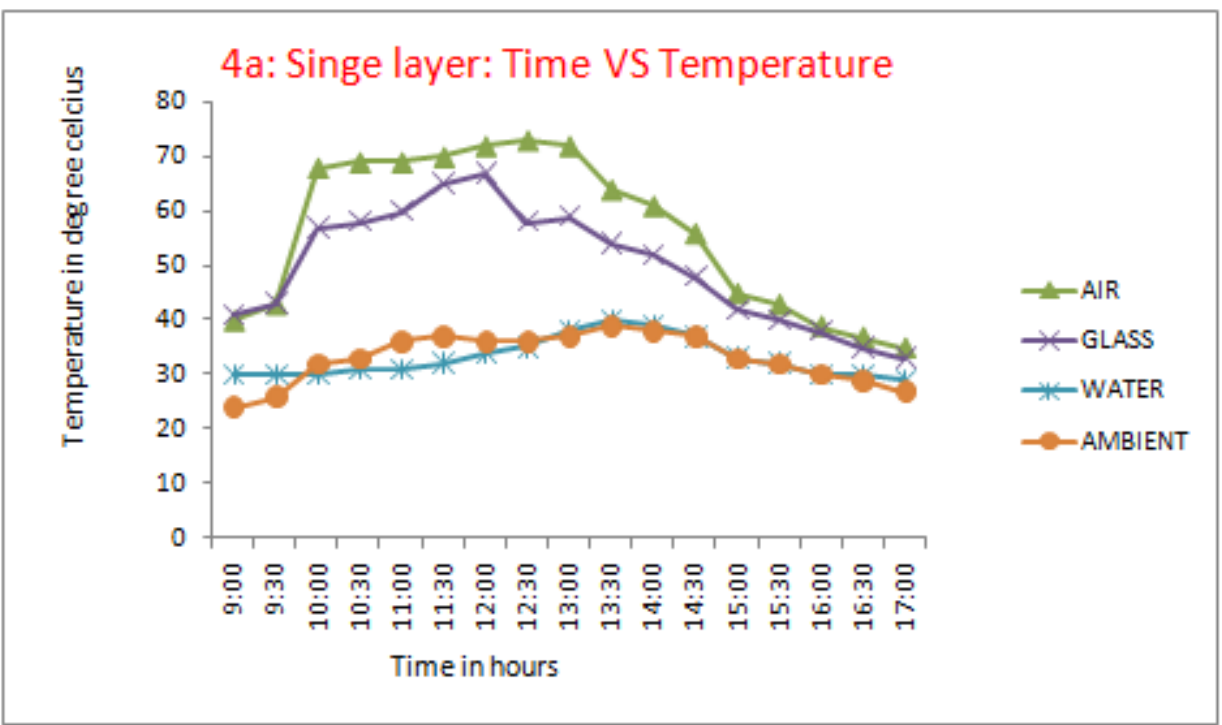

Figure 4a shows Single layer that variation of temperature for water, air, top cover ambient, inner cover and outer cover with respect to time.

The maximum temperature rise in water is $39^{\circ} \mathrm{C}$. Similarly the maximum air temperature of $73{ }^{\circ} \mathrm{C}$ is observed. During this study, the corresponding variation in ambient temperature is in the range of $24^{\circ} \mathrm{C}$ to $37^{\circ} \mathrm{C}$ and the variation of top cover temperature is in the range of $33{ }^{\circ} \mathrm{C}$ to $67{ }^{\circ} \mathrm{C}$

4b: Single layer: No. of days VS Radiation and Efficiency

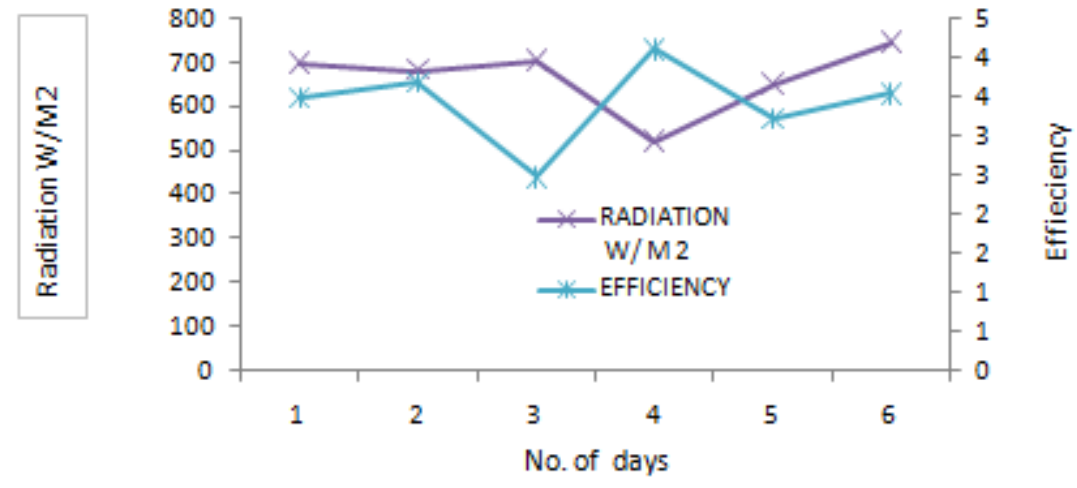

Figure $4 \mathrm{~b}$ shows variation of the daily mean solar radiation recorded during this study.

In this study mean daily radiation is obtained in the range of $521 \mathrm{~W} / \mathrm{M} 2$ to $748 \mathrm{~W} / \mathrm{M} 2$ is recorded and the variation of the efficiency is obtained in the range of $3 \%$ to $4 \%$ during the study of single layer. 


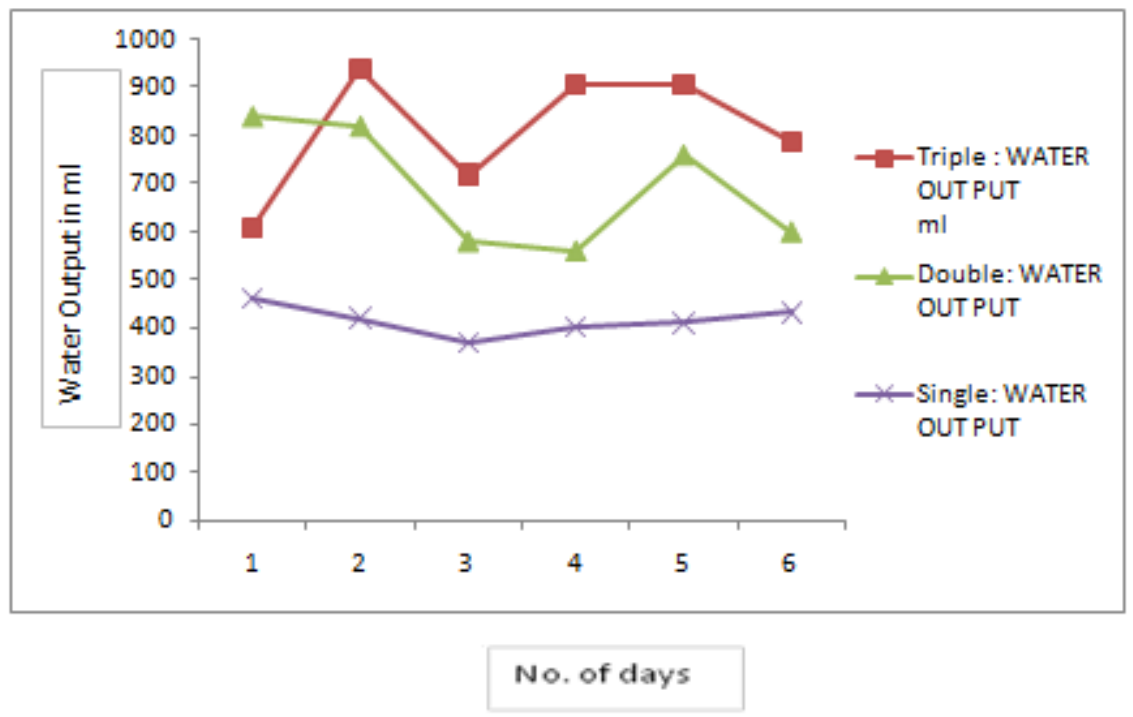

And also the variation of average Waterput of the still with number of days measured in this study. The average waterput is obtained in the range of $610 \mathrm{ml}$ to $940 \mathrm{ml}$ during the study with Triple layer and the average waterput is obtained in the range of $560 \mathrm{ml}$ to $840 \mathrm{ml}$ during the study with double layer. Then the average waterput is obtained in the range of $370 \mathrm{ml}$ to $460 \mathrm{ml}$ during the study with single layer.

The increase of observer surface area of planar cotton wick is helped to rise the water evaporation. Water is raised by weaved cotton wick due to capillary action from the basin to the absorber. Thus, the single slope solar still with more capillary rise under the multiple layer of wick shows that there is a significant increase in water collection.

\section{CONCLUSIONS}

The sewage water treatment is analysed through the solar desalination process. The Condensation process through solar still is taken for sewage water for the pupose of purification. The evaporation rate was mainly depends on the solar radiation. The purification rate was very excellent in sewage water.

\section{REFERENCES}

1. M. A. El-Khateeb, W. M. Emam, and W. A. Mohamed, "Essam Saber, integration of UASB and downflow hanging non-woven fabric $(D H N W)$ reactors for the treatment of sewage water," Desalination and Water Treatment, vol. 164, no. 48-55, 2019. View at: Publisher Site | Google Scholar

2. S. Ahsan, S. Kaneco, K. Ohta, T. Mizuno, and K. Kani, "Use of some natural and waste materials for waste water treatment, ”Water Research, vol. 35, no. 15, pp. 3738-3742, 2001.View at: $\underline{\text { Publisher Site | Google Scholar }}$

3. C. O. Ijagbemi, M.-H. Baek, and D.-S. Kim, "Montmorillonite surface properties and sorption characteristics for heavy metal removal from aqueous solutions," Journal of Hazardous Materials, vol. 166, no. 1, pp. 538-546, 2009.

4. M. M. Ali, E. E. El-Sayed, and M. Z. Kamel, "Removal of hazardous contaminants from wastewater using natural zeolite, "Journal of Water Research-Photon Foundation, vol. 138, pp. 333-347, 2017.

5. A. K. Bhattacharya, S. N. Mandal, and S. K. Das, "Adsorption of Zn(II) from aqueous solution by using different adsorbents, " Chemical Engineering Journal, vol. 123, no. 1-2, pp. 43-51, 2006. 
6. Langlais, B., Reckhow, D.A., and Brink, D.R. 1991. Ozone in water treatment: application and engineering. Lewis Publishers, Inc., Chelsea, Mich.

7. Wiesner, M.R., Hackney, J., Sethi, S., Jacangelo, J.G., and Laine, J.- M. 1994. Cost estimates for membrane filtration and conventional treatment. J. Am. Water Works Assoc. 85(12): 33-41.

8. Perkins, J. and Hunter, C. (2000). Removal of enteric bacteria in a surface flow constructed wetland in Yorkshire England. Wat. Res., 34(6), 1941- 1947.

9. Sinclair, R.G., Choi, C.Y., Riley, M.R., Gerba, C.P., 2008.Pathogen surveillance through mon-itoring of sewer systems. Adv. Appl. Microbiol. 65, 249-269.

10. Corman, V.M., Landt, O., Kaiser, M., Molenkamp, R., Meijer, A., Chu, D.K.W., Bleicker, T.,Brunink, S., Scheider, J., Schmidt, M.L., Mulders, D.G.J.C., Haagmans, B.L., van derVeer, B., van den Brink, S., Wijsman, L., Goderski, G., Romette, J.-L., Ellis, J., Zambon,M., Peiris, M., Goossens, H., Reusken, C., Koopman, M.P.G., Drosten, C., 2020.Detectionof 2019 novel coronavirus (2019-nCoV) by real-time RT-PCR. Euro Surveill. 25 (3),2000045.

11. Gao, Q.Y., Chen, Y.X., Fang, J.Y., 2020.2019 novel coronavirus infection and gastrointesti-nal tract. J. Dig. Dis. 1-2.

12. Snyder, W., Cook, M., Tipton, I., Nasset, E., Karhausen, L., and Howells, G. (1975). Reference man: Anatomical, physiological and metabolic characteristics (Report of Task Group on Reference Man-International Commission on Radiological Protection). New York, NY: Pergamon Press.

13. Henze, M., Harremoës, P., la Cour Jansen, J., and Arvin, E. (2001). Wastewater treatment: Biological and chemical processes (3rd ed.)

14. http://www.fao.org/3/w7224eOb.htm\#TopOfPage 